\title{
Transferrins Reduce Replication of Chlamydia suis in McCoy Cells
}

\author{
Leentje De Puysseleyr ${ }^{1}$, Kristien De Puysseleyr ${ }^{1}$, Joanna Rybarczyk ${ }^{1}$, Paulien Vander Donck ${ }^{1}$, \\ Winnok H. De Vos ${ }^{2,+}$ and Daisy Vanrompay ${ }^{1, *,+}$ \\ 1 Laboratory for Immunology and Animal Biotechnology, Faculty of Bioscience Engineering, Ghent University, \\ 9000 Ghent, Belgium; leentje.depuysseleyr@gmail.com (L.D.P.); kristien.depuysseleyr@gmail.com (K.D.P.); \\ j.rybarczyk@abcheckantibodies.com (J.R.); Paulien.VanderDonck@UGent.be (P.V.D.) \\ 2 Laboratory of Cell Biology and Histology, Faculty of Pharmaceutical, Biomedical and Veterinary Sciences, \\ University of Antwerp, 2610 Wilrijk, Belgium; winnok.devos@uantwerpen.be \\ * Correspondence: Daisy.Vanrompay@UGent.be \\ + Shared senior authorship.
}

check for updates

Citation: De Puysseleyr, L.; De Puysseleyr, K.; Rybarczyk, J.; Vander Donck, P.; De Vos, W.H.; Vanrompay, D. Transferrins Reduce Replication of Chlamydia suis in McCoy Cells. Pathogens 2021, 10, 858. https://doi.org/10.3390/ pathogens 10070858

Academic Editors: Martina Jelocnik and Hanna Marti

Received: 14 June 2021

Accepted: 4 July 2021

Published: 7 July 2021

Publisher's Note: MDPI stays neutral with regard to jurisdictional claims in published maps and institutional affiliations.

Copyright: (c) 2021 by the authors. Licensee MDPI, Basel, Switzerland. This article is an open access article distributed under the terms and conditions of the Creative Commons Attribution (CC BY) license (https:// creativecommons.org/licenses/by/ $4.0 /)$.

\begin{abstract}
Chlamydia suis (C. suis) resides in the intestines of pigs and tetracycline-resistant strains are emerging worldwide. Intestinal infections are often subclinical. However, the gut is regarded as a $C$. suis reservoir and clinical infections have been associated with enteritis, conjunctivitis, pneumonia and reproductive failure. C. suis was found in boar semen and venereal transmission occurred. We studied the anti-Chlamydia suis activity of ovotransferrin (ovoTF) and bovine lactoferrin (bLF). Pre-incubation of $C$. suis with bLF or ovoTF had no significant effect on overall chlamydia replication (mean fluorescence area) in McCoy cells. The addition of ovoTF to the culture medium had no effect on bacterial replication, but the addition of 0.5 or $5 \mathrm{mg} / \mathrm{mL}$ of bLF significantly reduced the inclusion size by $17 \%$ and $15 \%$ respectively. Egg components are used for cryopreservation of boar semen. When inoculating an ovoTF-containing and Chlamydia suis-spiked semen sample in McCoy cells, a significant reduction in inclusion number (by $7 \%$ ) and overall replication (by 11\%) was observed. Thus, we showed that transferrins possess anti-chlamydial activity. Moreover, ovoTF addition to semen extenders might reduce $C$. suis venereal transmission. Further research is needed to unravel the mechanisms behind the observations and to enhance the effect of transferrins on C. suis.
\end{abstract}

Keywords: Chlamydia suis; swine; transferrin; ovotransferrin; lactoferrin

\section{Introduction}

The genus Chlamydia consists of obligate intracellular bacterial species that cause disease in a broad range of host animals. Chlamydia suis (C. suis) is considered endemic in the intestinal flora of pigs [1]. Although these intestinal C. suis infections are widespread, they usually remain subclinical $[2,3]$. However, C. suis infections in pigs can also lead to enteritis, conjunctivitis, pneumonia and reproductive failure in sows and boars, leading to economic loss [4-6]. Moreover, the presence of C. suis in pig semen has already been demonstrated and suggested as a possible route of transmission among pigs [7-9]. Tetracycline is the main antibiotic used in the treatment of chlamydial infections. However, since 1998, tetracyclineresistant $C$. suis strains have been emerging worldwide [8,10-17]. Alternatives to antibiotics are urgently needed, as antimicrobial resistance is an increasingly important concern for both human and animal health [18]. Furthermore, there is considerable pressure to diminish antibiotic use in animal production. A critical component of the antimicrobial resistance solution is the development of truly novel and innovative alternatives to antibiotics to cover not only the diminishing effectiveness of existing antibiotics but also to support sustainable antibiotic use, preserving them exclusively for treatment of life-threatening infections. 
Transferrins might present an alternative to antibiotics. Lactoferrin (LF), ovotransferrin (ovoTF), and serum transferrin, are the most important members of the transferrin family of iron-binding glycoproteins. The function of this protein family is not solely limited to iron-transport [19-21].

Lactoferrin is secreted by the mucosal epithelial cells of multiple species, including cows, goats, horses and humans. Consequently, this transferrin is present in tears, saliva, vaginal secretions, semen and, most abundantly, in milk. Lactoferrin is present in neutrophil granules from where it is released upon inflammation. As such, LF is involved in the modulation of the inflammatory response to pathogens [22]. Lactoferrin can bind and sequester lipopolysaccharide (LPS), thus preventing pro-inflammatory pathways, sepsis and tissue damage. However, LF-bound LPS may retain the capacity to induce cell activation via Toll-like receptor 4-dependent and -independent mechanisms [23]. Lactoferrin acts as a primary defense against pathogenic bacteria, viruses, fungi and protozoa. Its function as an antimicrobial protein or peptide is most studied and is based on multiple mechanisms [24]. Lactoferrin has a bacteriostatic effect through iron-binding, leading to iron deprivation of the microorganisms. In addition, LF affects bacteria directly by destabilizing the outer membrane of Gram-negative bacteria through binding of bacterial LPS [25-28]. Moreover, LF can cause selective permeation of ions through the inner membrane [29], and it interferes with bacterial adherence on host cells through disruption of the bacterial Type III secretion system (TTSS) [24,30,31]. Lactoferrin not only binds endotoxins (LPS), it also influences the release and bioactivity of Shiga toxins from enterohemorrhagic Escherichia coli O157:H7 (EHEC) strains [32], and it degrades F4 fimbriae, F18 fimbriae and flagellin of porcine EHEC strains. Lactoferrin can also decrease the number of adherent bacteria to porcine small intestinal epithelial cells [33].

Ovotransferrin is produced by birds and is predominantly present in serum and egg white. Similar to LF, ovoTF has a role in iron transportation and delivery [34]. Moreover, it also exerts antimicrobial effects on Gram-negative bacteria [35] through permeation of the outer membrane followed by selective permeation of ions through the inner membrane leading to disruption of the electric potential $[29,36,37]$. This bactericidal activity can be attributed to the amino-terminal N-lobe of ovoTF from which the cationic antimicrobial peptide OTAP-92, consisting of 92 amino acids, was derived. Ovotransferrin degrades F18 fimbriae and flagellin, but not F4 fimbriae of porcine EHEC strains, and decreases the number of adherent bacteria to porcine small intestinal epithelial cells [33].

Lactoferrin and ovoTF have already proven their potential to reduce chlamydial infections in vitro and in vivo. Beeckman et al. [38] was the first to demonstrate the inhibitory effect of human lactoferrin (hLF), bovine lactoferrin (bLF) and ovoTF on the infectivity, adhesion and invasion of $C$. psittaci in HD11 chicken macrophages. The same group also successfully used ovoTF spraying to prevent $C$. psittaci respiratory disease in experimentally infected specific pathogen-free turkeys and on a commercial turkey broiler farm [39-41]. Farm use of ovoTF: (i) reduced the amount of C. psittaci in the air, as demonstrated by bioaerosol monitoring; (ii) prevented respiratory disease during the first half of the brood period; (iii) was associated with a $46 \%$ reduction in mortality; and (iv) reduced the antibiotic cost [40].

Currently, the antibacterial activity of transferrins towards C. suis has not been investigated. In order to evaluate the use of bLF and ovoTF against C. suis infections in pigs, we examined the effect of these transferrins on extracellular C. suis and on intracellular replication of $C$. suis S45 in vitro. Additionally, the use of ovoTF to reduce the in vitro infectivity of $C$. suis in spiked boar semen was evaluated.

\section{Results}

To determine the maximal non-cytotoxic concentration of ovoTF and bLF for McCoy cells, a 3-[4,5-dimethylthiazole-2-yl]-2,5-diphenyltetrazolium bromide (MTT) assay was performed. Up to $2.5 \mathrm{mg} / \mathrm{mL}$ of ovoTF and $10 \mathrm{mg} / \mathrm{mL}$ of bLF did not affect the cellular metabolism at the time points examined. At $24 \mathrm{~h}$ and $48 \mathrm{~h}, 5 \mathrm{mg} / \mathrm{mL}$ of ovoTF decreased 
the cellular metabolism by $50 \%$. At $24 \mathrm{~h}$ and $48 \mathrm{~h}, 10 \mathrm{mg} / \mathrm{mL}$ of ovoTF reduced cellular metabolism by $85 \%$ and $90 \%$, respectively. Only non-cytotoxic concentrations of $0.5 \mathrm{mg} / \mathrm{mL}$ of ovoTF, $0.5 \mathrm{mg} / \mathrm{mL}$ of bLF and $5 \mathrm{mg} / \mathrm{mL}$ of bLF were further used.

To evaluate the effect on extracellular bacteria, C. suis S45 bacteria were incubated with transferrins prior to inoculation in McCoy cells. Pre-incubation of C. suis with ovoTF or bLF had no significant effect on the inclusion number, inclusion size, or overall replication in McCoy cells (Figure 1). A repetition in time gave the same result: no significant effects were observed (data not shown).

\section{(a) Pre-incubation}
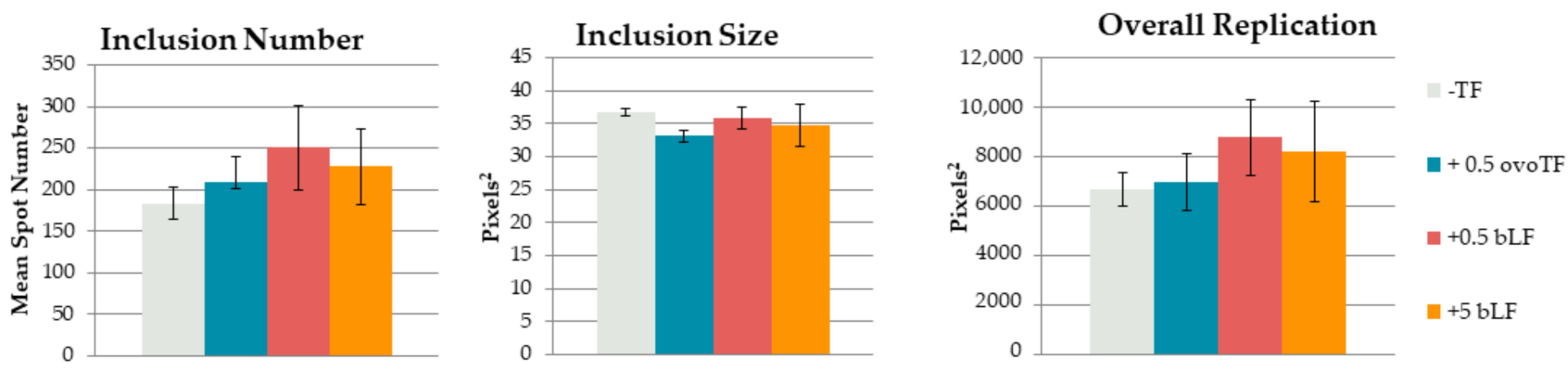

\section{(b) Post-incubation}
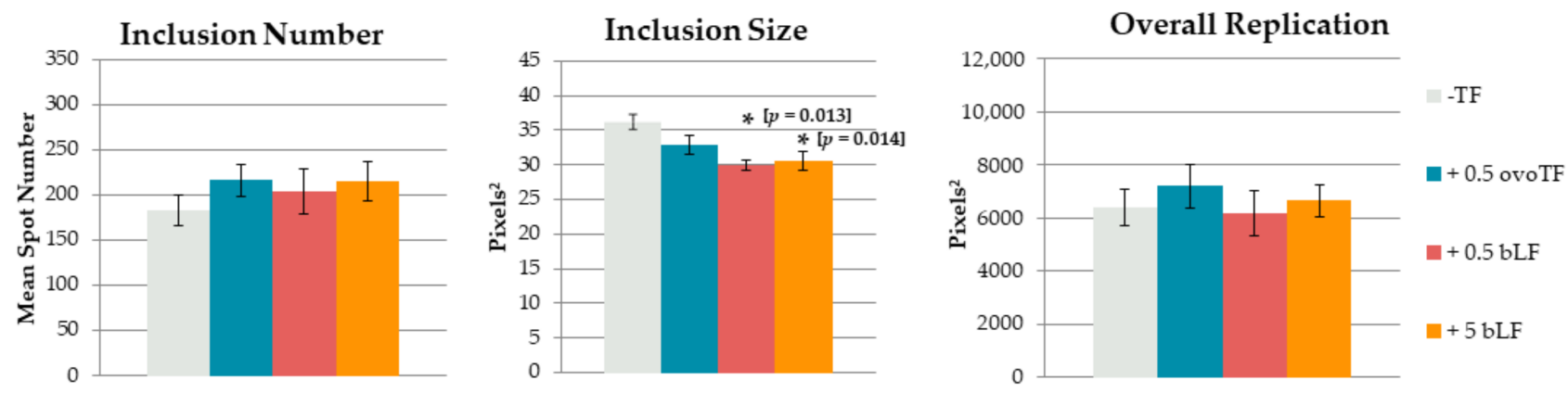

Figure 1. Effect of transferrins (TF) on Chlamydia (C.) suis. (mean $\pm \mathrm{SE}$ ). C. suis was incubated with ovotransferrin (ovoTF) and bovine lactoferrin (bLF) (a) prior to inoculation (pre-incubation) and (b) from inoculation onward (post-incubation). Replication of $C$. suis was compared based on inclusion number (mean spot number), inclusion size (mean spot area) and overall replication (mean fluorescent area) in McCoy cells. Significant differences as compared to the control are designated with an asterisk, accompanied by their $p$-value.

To assess the influence of transferrins on intracellular replicating bacteria, incubation with transferrins was performed post-inoculation (p.i.). The addition of $0.5 \mathrm{or} 5 \mathrm{mg} / \mathrm{mL}$ of bLF to the culture medium lowered the number of inclusions, as well as the overall replication, albeit not significantly as compared to the control. The inclusion size was significantly reduced by adding bLF to the culture medium. As compared to the control, the inclusion size was reduced by $17 \%(p=0.013)$ and $15 \%(p=0.014)$ when incubating with 0.5 or $5 \mathrm{mg} / \mathrm{mL}$ of bLF, respectively (Figure 1). However, there was no significant dose effect. Supplementing ovoTF to the culture medium had no significant effect on the inclusion number, inclusion size or overall replication. A repetition in time gave the same result, namely only significant effects on the inclusion size when using 0.5 and $5 \mathrm{mg} / \mathrm{mL}$ of bLF (data not shown).

To prevent venereal spread of $C$. suis, an experiment was set up to examine the effect of adding ovotransferrin to $C$. suis spiked pig semen, as chicken egg components are already used for cryopreservation of boar semen. First, all three boars tested negative in C. suis real-time PCR and C. suis recombinant MOMP-based antibody ELISA. When inoculating the ovoTF treated, or non-treated, C. suis spiked semen samples in McCoy cells, 
a significant reduction in the inclusion number [reduced by $7 \%(p=0.018)$ ] and overall replication [reduced by $11 \%(p<0.001)$ ] was observed for the treated sample (Figure 2$)$. A repetition, using semen of another $C$. suis negative boar, gave the same result, namely a significant reduction in the inclusion number and overall replication (data not shown).
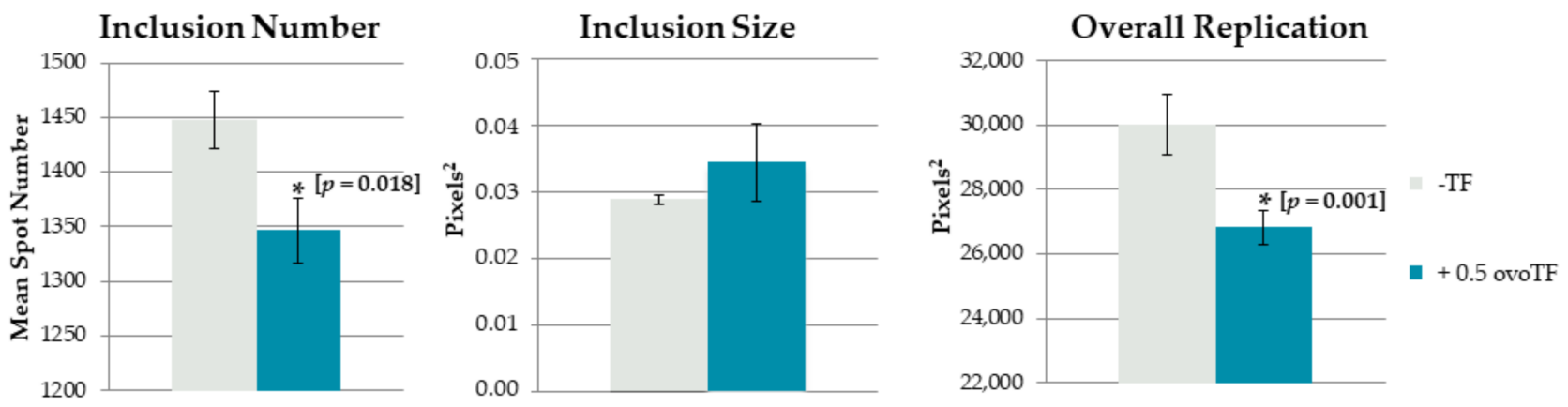

Figure 2. Effect of ovotransferrin (ovoTF) on Chlamydia (C.) suis-spiked pig semen. (mean \pm SE) C. suis was added to negative pig semen and incubated with or without $0.5 \mathrm{mg} / \mathrm{mL}$ of ovoTF prior to inoculation. Replication of $C$. suis was compared based on inclusion number (mean spot number), inclusion size (mean spot area) and overall replication (mean fluorescent area) in McCoy cells. Significant differences are designated with an asterisk, accompanied by their $p$-value.

\section{Discussion}

The anti-bacterial effect of transferrins has already been described for Gram-positive and Gram-negative bacteria [34,42]. Currently, the anti-chlamydial effect of transferrins has only been demonstrated for the avian pathogen C. psittaci [38-40] and, more recently, for the human pathogen C. trachomatis [43]. Emerging tetracycline resistance in C. suis strains in the domestic pig population worldwide [8,10-17] requires the development of alternative preventive strategies or therapeutics. Therefore, we examined the effect of transferrins towards the C. suis reference strain S45.

Bacteria were incubated with transferrins prior to inoculation in McCoy cells or from inoculation onward. Pre-incubation of $C$. suis with ovoTF or bLF prior to inoculation in McCoy cells had no significant effect on the number of inclusions, the inclusion size or the overall replication, suggesting no effect on extracellular bacteria. Beeckman et al. [38] performed a similar, but not identical, trial for the avian pathogen C. psittaci: pre-incubating

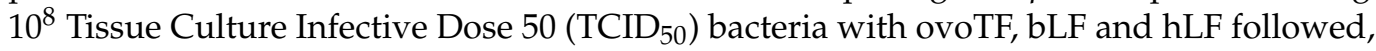
by inoculation in BGM cells. They noticed a significant reduction in the infection outcome when pre-incubating C. psittaci with 0.5 to $5.0 \mathrm{mg} / \mathrm{mL}$ of ovoTF, followed by inoculation in BGM cells. Bovine and human LF had no significant effect on the infectivity of $C$. psittaci. Therefore, in their study, the avian transferrin acted better on the avian extracellular chlamydiae. This might suggest that porcine LF would be better for reducing the infectivity of extracellular C. suis. However, this can only be proven by using the identical experimental conditions used by Beeckman et al. [38]. Therefore, a batch of recombinant porcine LF is currently being produced, as described by Dierick et al. [33], to examine this hypothesis in depth by using the previously described method [38]. We already used this recombinant porcine LF ( $\mathrm{pLF}$ ) successfully in in vitro studies with porcine enterotoxigenic Escherichia coli [33]. However, recombinant pLF is much more expensive compared to ovoTF or bLF, and thus less attractive for use in the pig industry. One could use native pLF purified from sow colostrum or milk. However, native pLF is commercially unavailable for two reasons: (1) pLF concentrations in sow colostrum and milk are rather low and (2) the 'successful' pig breeding programs $[44,45]$ resulted in larger litters but, unfortunately, also in a shortage of colostrum and milk for the piglets, as colostrum and milk production by the sow remained unchanged. This is in contrast with the large availability of ovoTF or bLF from chicken egg whites or cow milk.

Incubation of C. suis-inoculated McCoy cells with ovoTF had no significant effect on inclusion number, inclusion size or overall replication. Bovine LF, on the other hand, 
significantly reduced inclusion size. The number of inclusions and the overall replication of $C$. suis were also reduced by bLF, albeit not significantly. However, no dose effects were observed for bLF. The latter might perhaps be explained by the transferrin receptors present on McCoy cells. In this experiment, effects on intracellular chlamydiae can only occur when ovoTF or bLF are able to enter McCoy cells (mouse fibroblasts), as recently shown by us for bLF in bovine primary rectal cells [46]. The presence or absence of transferrin receptors (intelectin, nucleolin) on McCoy cells might be verified by RT-PCR and immunofluorescence assays but given, bLF has an effect, its receptor must be present. Furthermore, the ovoTF receptor must be expressed on McCoy cells, as our semen experiment demonstrated an effect for ovoTF.

Chlamydia suis can be venereally transmitted via contaminated boar semen [7-9]. Schautteet et al. [8] examined a case of severe reproductive failure in a Israeli pig farrowing to slaughter farm. The Israeli farm most likely became accidently infected with $C$. suis through the import of boar semen from a German boar insemination center, as $C$. suis was retrospectively isolated from the semen of four out of five boar studs used. National and international trade of boar semen for insemination is common. Semen for artificial insemination is typically obtained from high health and specific pathogen-free herds. They are frequently tested for porcine reproductive and respiratory viruses (PRRSV) and, on occasion, other porcine viruses via PCR to avoid transmission. Screening does not regularly include bacteria and, as far as we know, does not include C. suis, which is a relatively 'new' emerging pathogen in the pig industry. Furthermore, the addition of antibiotics in commercially available extenders is generally believed to limit or preclude the transmission of infectious bacteria. However, Hamonic et al. [9] have already reported extended boar semen used for artificial insemination as a potential transmission mechanism for C. suis. Chlamydia suis remained viable and infectious during chilled storage and was globally unaffected by antibiotics (penicillin, streptomycin, gentamycin) in the extender.

Therefore, we evaluated the effects of ovotransferrin on the replication of $C$. suis from spiked pig semen samples in vitro. Ovotransferrin is the second most abundant $(12 \%)$ protein present in egg whites, following ovalbumin $(54 \%)$, and is purified from chicken eggs on industrial scale. OvoTF ( \pm EUR $200 / \mathrm{kg}$ ) is cheaper than bLF ( \pm EUR $800 / \mathrm{kg}$ ) and thus more attractive to the pig industry. Furthermore, egg material, namely egg yolk, is widely used for boar semen cryopreservation [47]. Incubation of C. suisspiked negative pig semen with $0.5 \mathrm{mg} / \mathrm{mL}$ of ovoTF resulted in a significant reduction in the number of inclusions formed during the cultivation of $C$. suis from pig semen in cell monolayers. Moreover, the overall replication of $C$. suis was significantly reduced. These findings are contradictory to the results of the post-incubation experiment with ovoTF, which showed no effect on S45. However, the constitution of the semen sample, for instance the bicarbonate (mainly originating from the seminal vesicles) or salt (epididymal fluid) concentrations, could have influenced the activity of ovoTF in semen. Indeed, Ko et al. [48] demonstrated that the addition of bicarbonate enhanced ovoTF antimicrobial activities against Escherichia coli O157:H7. Moreover, bicarbonate, involved in the initial binding of iron to ovoTF, enhanced the activity of ovoTF towards Staphylococci species [49]. Additionally, the antimicrobial activity of ovoTF against Salmonella enterica depended on the salt composition of the medium, which either favored or interfered with binding of ovoTF to the bacterial surface [50].

The observed anti-chlamydial effects were rather minimal. Nevertheless, they justify further research, especially on the activity of porcine lactoferrin on C. suis when inoculated into porcine lactoferrin receptor-expressing swine cells and/or the use of the less expensive ovoTF as an additive to semen extenders. Optimization of the ovotransferrin concentration and the addition of ovoTF activity enhancers could also be examined. Furthermore, although ovoTF seemed to have no effect on the semen cell morphology of spiked semen samples, evaluation of semen quality in the presence of ovoTF needs to be examined thoroughly. 


\section{Materials and Methods}

\subsection{Chlamydia suis, Cell Culture and Transferrins}

The effect of transferrins on C. suis S45 [51] was examined using McCoy cells (mouse fibroblast cells, CRL-1696 American Type Culture Collection), cultured in Eagle's minimal essential medium (Thermo Fisher Scientific, Paisley, UK), following standard procedures [52]. McCoy cells were used, as $\$ 45$ grows significantly better in these cells compared to, for instance, SK6 and Vero cells [53]. Titration of the S45 stock was performed by the method used by Spearman and Karber [54], which determined the TCID 50 .

Ovotransferrin and bLF purified from chicken egg whites and bovine colostrum were purchased from Bioseutica (Fordras, Lugano, Switzerland) and Sigma (Bornem, Belgium), respectively. For each experiment, a fresh stock solution of transferrins $(50 \mathrm{mg}$ transferrin per $\mathrm{mL}$ cell culture medium) was prepared and filter sterilized $(0.22 \mu \mathrm{m}$; Merck Millipore, Overijse, Belgium).

\subsection{Transferrin Cytotoxicity Assay}

The putative cytotoxicity of transferrins for McCoy cells was determined by the MTT assay, as described in [38]. The MTT assay is a colorimetric assay for assessing cell metabolic (mitochondrial) activity. Monolayers in 96-well plates (Greiner BioOne, Wemmel, Belgium) were exposed (in duplicate) to zero, $0.5,1,2.5,5$ and $10 \mathrm{mg} / \mathrm{mL}$ of transferrins in culture medium. At 24 and $48 \mathrm{~h}$, cytotoxicity was determined. The experiment was repeated once.

\subsection{Effect of Transferrins on C. suis Infectivity and Replication in McCoy Cells}

Pre-incubation of $C$. suis with transferrins prior to inoculation allowed us to examine its effect on the infectivity of extracellular bacteria. Bacteria $\left(10^{8} \mathrm{TCID}_{50} / \mathrm{mL}\right)$ were incubated at $37{ }^{\circ} \mathrm{C}$ for $1 \mathrm{~h}$ in McCoy culture medium supplemented with $0.5 \mathrm{mg} / \mathrm{mL}$ of ovoTF, $0.5 \mathrm{mg} / \mathrm{mL}$ of bLF or $5.0 \mathrm{mg} / \mathrm{mL}$ of bLF. Concentrations were selected based on transferrin cytotoxicity results for McCoy cells and earlier in vitro experiments with C. psittaci [38]. Next, treated and non-treated (controls) bacteria $(100 \mu \mathrm{L})$ were inoculated on McCoy cells grown on sterile glass coverslips (Chlamydia Trac bottles; Sterilin Ltd., Stone, UK); the monolayers were washed and culture medium was added.

To assess the effect of transferrins on intracellular chlamydiae, McCoy cells grown on sterile glass coverslips were inoculated $(100 \mu \mathrm{L})$ with C. suis $\mathrm{S} 45\left(10^{8} \mathrm{TCID}_{50} / \mathrm{mL}\right)$, following standard procedures [52]. Monolayers were washed to remove unattached chlamydiae and culture medium with no transferrins (controls), $0.5 \mathrm{mg} / \mathrm{mL}$ of ovoTF, $0.5 \mathrm{mg} / \mathrm{mL}$ of bLF or $5 \mathrm{mg} / \mathrm{mL}$ of bLF was added.

For each of the above-mentioned assays, monolayers were stained at $40 \mathrm{~h}$ p.i. and bacterial replication was quantified by Imagen ${ }^{\mathrm{TM}}$ Chlamydia immunofluorescence staining (Oxoid, Thermo Fisher Scientific, Drongen, Belgium), staining the cell nuclei with DAPI (Life Technologies, Belgium). Quadruplicates were always used. All inoculation trials were repeated once.

\subsection{Effect of Ovotransferrin on C. suis Spiked Pig Semen}

OvoTF was tested as an anti-chlamydial semen additive. First, 3 boar semen samples (artificial insemination center, Flanders, Belgium) were examined with a C. suis real-time PCR [55], and blood samples were analyzed using a C. suis recombinant MOMP-based ELISA [56] to select one negative boar for spiking assays. Then, $6 \mathrm{~mL}$ of fresh, undiluted semen from the selected C. suis negative boar was divided into two equal parts. Subsequently, each sample was spiked with $10^{8} \mathrm{TCID}_{50}$ C. suis bacteria. Sample one $(3 \mathrm{~mL})$ was incubated for $1 \mathrm{~h}$ at $37^{\circ} \mathrm{C}$ in the presence of $0.5 \mathrm{mg} / \mathrm{mL}$ of ovoTF, while sample two $(3 \mathrm{~mL})$ was incubated in the same way, adding only cell culture medium (control). Afterwards, $100 \mu \mathrm{L}$ of the semen samples was inoculated onto McCoy cells [52]. Monolayers were washed to remove unattached bacteria and culture medium, with or without ovoTF $(0.5 \mathrm{mg} / \mathrm{mL})$, was added. At $40 \mathrm{~h}$ p.i., the replication of C. suis was examined using Imagen ${ }^{\mathrm{TM}}$ Chlamydia 
immunofluorescence staining. Quadruplicates were used. The experiment was repeated once with semen of another C. suis-negative boar.

\subsection{High Content Microscopy and Image Analysis}

A fully automated inverted Nikon Ti widefield fluorescence microscope (Nikon Instruments, Paris, France) was used, equipped with a motorized XYZ stage and filter cube turret and shutters. Samples were magnified with a $40 \times$ Plan Fluor oil objective (numerical aperture of 1.3) and images were acquired with an Andor Ixon EM-CCD camera, yielding a pixel size of $0.276 \mu \mathrm{m} /$ pixel. To obtain a representative sample of each condition with minimal edge effects, three separate, but sufficiently central, regions were chosen per slide. Per region, a 5-dimensional hyperstack was recorded, consisting of 16 fields (acquired as a mosaic of $4 \times 4$ juxtaposed fields), 5-7 Z-slices (separated by $1 \mu \mathrm{m}$ ) and 2 channels (DAPI and FITC).

To analyze the multidimensional image data sets, a dedicated macro script for FIJI image analysis freeware (http:/ / fiji.sc, version 1.53c [57]) was used as described before [53,58] Briefly, the analysis consists of a stepwise segmentation of regions of interest (nuclei and Chlamydia inclusions), followed by a quantification of their size and number. Before commencing segmentation, hyperstacks were projected along the Z-axis according to the maximum intensity. Then, putative Chlamydia inclusions were segmented. To this end, the FITC channel image was convolved with a Laplacian filter to enhance the focal signals (spots), which were automatically thresholded using the Isodata algorithm. Only spots larger than 3 pixels were retained. Subsequently, nuclei were segmented in the DAPI channel after Gaussian smoothing using the Isodata auto threshold algorithm, followed by a binary watershed procedure to separate touching nuclei. Finally, cellular regions of influence were determined by Voronoi tessellation on the binary mask of nuclear regions detected in the image. Per cellular region of influence, the mean spot area (a measure for inclusion size per field), mean spot number (a measure for inclusion number per field) and mean fluorescent area (total inclusion size per field, a proxy for the overall replication) were determined.

\subsection{Statistical Analysis}

The mean and standard error were calculated for the number of inclusions, inclusion size and overall replication. Assumptions of normality and homoscedasticity were checked, and data were transformed in case of non-normality or heteroscedasticity. For all parameters, transferrin concentrations were compared using one-way ANOVA, followed by Tukey HSD post hoc tests $(p<0.05)$. All data were analyzed using TIBCO Spotfire $\mathrm{S}^{\circledR}{ }^{\circledR}$ 8.2 (Tibco Software Inc., Palo Alto, CA, USA).

Author Contributions: Conceptualization, D.V. and W.H.D.V.; methodology, D.V., W.H.D.V. and J.R.; software, W.H.D.V.; investigation, L.D.P. and K.D.P.; writing—original draft preparation, L.D.P.; writing - review and editing D.V., W.H.D.V. and P.V.D.; funding acquisition, D.V. All authors have read and agreed to the published version of the manuscript.

Funding: This research was funded by Federal Public Service of Health, Safety of the Food Chain and Environment (convention RF-10/6234).

Institutional Review Board Statement: Not applicable.

Informed Consent Statement: Not applicable.

Data Availability Statement: The script for analysis is available upon request.

Acknowledgments: R. Goedegebuure (Nuscience, Drongen, Belgium) is acknowledged for providing the boar semen samples.

Conflicts of Interest: The authors declare no conflict of interest. The funders had no role in the design of the study; in the collection, analyses, or interpretation of data; in the writing of the manuscript, nor in the decision to publish the results. 


\section{References}

1. Aumayer, H.; Leonard, C.A.; Pesch, T.; Prähauser, B.; Wunderlin, S.; Guscetti, F.; Borel, N. Chlamydia suis Is Associated with Intestinal NF-KB Activation in Experimentally Infected Gnotobiotic Piglets. Pathog. Dis. 2020, 78, ftaa040. [CrossRef]

2. Li, M.; Jelocnik, M.; Yang, F.; Gong, J.; Kaltenboeck, B.; Polkinghorne, A.; Feng, Z.; Pannekoek, Y.; Borel, N.; Song, C.; et al. Asymptomatic Infections with Highly Polymorphic Chlamydia Suis Are Ubiquitous in Pigs. BMC Vet. Res. 2017, 13, 370. [CrossRef]

3. Rypuła, K.; Kumala, A.; Płoneczka-Janeczko, K.; Lis, P.; Karuga-Kuźniewska, E.; Dudek, K.; Całkosiński, I.; Kuźnik, P.; Chorbiński, P. Occurrence of Reproductive Disorders in Pig Herds with and without Chlamydia Suis Infection-Statistical Analysis of Breeding Parameters. Anim. Sci. J. 2018, 89, 817-824. [CrossRef]

4. Schautteet, K.; Vanrompay, D. Chlamydiaceae Infections in Pig. Vet. Res. 2011, 42, 29. [CrossRef]

5. Chahota, R.; Ogawa, H.; Ohya, K.; Yamaguchi, T.; Everett, K.D.E.; Fukushi, H. Involvement of Multiple Chlamydia Suis Genotypes in Porcine Conjunctivitis. Transbound. Emerg. Dis. 2018, 65, 272-277. [CrossRef]

6. Hoque, M.M.; Adekanmbi, F.; Barua, S.; Rahman, K.S.; Aida, V.; Anderson, B.; Poudel, A.; Kalalah, A.; Bolds, S.; Madere, S.; et al. Peptide ELISA and FRET-QPCR Identified a Significantly Higher Prevalence of Chlamydia Suis in Domestic Pigs than in Feral Swine from the State of Alabama, USA. Pathogens 2021, 10, 11. [CrossRef] [PubMed]

7. Kauffold, J.; Melzer, F.; Henning, K.; Schulze, K.; Leiding, C.; Sachse, K. Prevalence of Chlamydiae in Boars and Semen Used for Artificial Insemination. Theriogenology 2006, 65, 1750-1758. [CrossRef]

8. Schautteet, K.; de Clercq, E.; Miry, C.; van Groenweghe, F.; Delava, P.; Kalmar, I.; Vanrompay, D. Tetracycline-Resistant Chlamydia Suis in Cases of Reproductive Failure on Belgian, Cypriote and Israeli Pig Production Farms. J. Med. Microbiol. 2013, 62, 331-334. [CrossRef]

9. Hamonic, G.; Pasternak, J.A.; Käser, T.; Meurens, F.; Wilson, H.L. Extended Semen for Artificial Insemination in Swine as a Potential Transmission Mechanism for Infectious Chlamydia Suis. Theriogenology 2016, 86, 949-956. [CrossRef]

10. Andersen, A.A.; Rogers, D.G. Resistance to Tetracycline and Sulfadiazine in Swine C. Trachomatis Isolates. In Chlamydial Infections, Proceedings of the Ninth International Symposium on Human Chlamydial Infection, Napa, CA, USA, 21-26 June 1998; Stephens, R.S., Ed.; International Chlamydia Symposium: San Francisco, CA, USA, 1998; pp. 313-316.

11. Di Francesco, A.; Donati, M.; Rossi, M.; Pignanelli, S.; Shurdhi, A.; Baldelli, R.; Cevenini, R. Tetracycline-Resistant Chlamydia Suis Isolates in Italy. Vet. Rec. 2008, 163, 251-252. [CrossRef]

12. Borel, N.; Regenscheit, N.; Di Francesco, A.; Donati, M.; Markov, J.; Masserey, Y.; Pospischil, A. Selection for Tetracycline-Resistant Chlamydia Suis in Treated Pigs. Vet. Microbiol. 2012, 156, 143-146. [CrossRef]

13. Donati, M.; Balboni, A.; Laroucau, K.; Aaziz, R.; Vorimore, F.; Borel, N.; Morandi, F.; Vecchio Nepita, E.; Di Francesco, A. Tetracycline Susceptibility in Chlamydia Suis Pig Isolates. PLoS ONE 2016, 11, e0149914. [CrossRef]

14. Wanninger, S.; Donati, M.; Di Francesco, A.; Hässig, M.; Hoffmann, K.; Seth-Smith, H.M.B.; Marti, H.; Borel, N. Selective Pressure Promotes Tetracycline Resistance of Chlamydia Suis in Fattening Pigs. PLoS ONE 2016, 11, e0166917. [CrossRef]

15. Marti, H.; Kim, H.; Joseph, S.J.; Dojiri, S.; Read, T.D.; Dean, D. Tet(C) Gene Transfer between Chlamydia Suis Strains Occurs by Homologous Recombination after Co-Infection: Implications for Spread of Tetracycline-Resistance among Chlamydiaceae. Front. Microbiol. 2017, 8, 156. [CrossRef]

16. Seth-Smith, H.M.B.; Wanninger, S.; Bachmann, N.; Marti, H.; Qi, W.; Donati, M.; di Francesco, A.; Polkinghorne, A.; Borel, N. The Chlamydia Suis Genome Exhibits High Levels of Diversity, Plasticity, and Mobile Antibiotic Resistance: Comparative Genomics of a Recent Livestock Cohort Shows Influence of Treatment Regimes. Genome Biol. Evol. 2017, 9, 750-760. [CrossRef]

17. Unterweger, C.; Schwarz, L.; Jelocnik, M.; Borel, N.; Brunthaler, R.; Inic-Kanada, A.; Marti, H. Isolation of Tetracycline-Resistant Chlamydia Suis from a Pig Herd Affected by Reproductive Disorders and Conjunctivitis. Antibiotics 2020, 9, 187. [CrossRef]

18. European Medicines Agency. ESVAC: Vision, Strategy and Objectives 2016-2020 European Surveillance of Veterinary Antimicrobial Consumption; European Medicines Agency: Amsterdam, The Netherlands, 2016.

19. Legrand, D. Overview of Lactoferrin as a Natural Immune Modulator. J. Pediatr. 2016, 173S, S10-S15. [CrossRef]

20. Rosa, L.; Cutone, A.; Lepanto, M.S.; Paesano, R.; Valenti, P. Lactoferrin: A Natural Glycoprotein Involved in Iron and Inflammatory Homeostasis. Int. J. Mol. Sci. 2017, 18, 1985. [CrossRef]

21. Dierick, M.; Vanrompay, D.; Devriendt, B.; Cox, E. Lactoferrin, a Versatile Natural Antimicrobial Glycoprotein That Modulates the Host's Innate Immunity. Biochem. Cell Biol. 2021, 99, 61-65. [CrossRef]

22. Kieckens, E.; Rybarczyk, J.; Cox, E.; Vanrompay, D. Antibacterial and Immunomodulatory Activities of Bovine Lactoferrin against Escherichia Coli O157:H7 Infections in Cattle. BioMetals 2018, 31, 321-330. [CrossRef]

23. Latorre, D.; Puddu, P.; Valenti, P.; Gessani, S. Reciprocal Interactions between Lactoferrin and Bacterial Endotoxins and Their Role in the Regulation of the Immune Response. Toxins 2010, 2, 54-68. [CrossRef]

24. Rybarczyk, J.; Kieckens, E.; Vanrompay, D.; Cox, E. In Vitro and in Vivo Studies on the Antimicrobial Effect of Lactoferrin against Escherichia Coli O157:H7. Vet. Microbiol. 2017, 202, 23-28. [CrossRef]

25. Ellison, R.T.; Giehl, T.J.; LaForce, F.M. Damage of the Outer Membrane of Enteric Gram-Negative Bacteria by Lactoferrin and Transferrin. Infect. Immun. 1988, 56, 2774-2781. [CrossRef]

26. Ellison, R.T.; LaForce, F.M.; Giehl, T.J.; Boose, D.S.; Dunn, B.E. Lactoferrin and Transferrin Damage of the Gram-Negative Outer Membrane Is Modulated by $\mathrm{Ca}^{2+}$ and $\mathrm{Mg}^{2+}$. J. Gen. Microbiol. 1990, 136, 1437-1446. [CrossRef] 
27. Brandenburg, K.; Jürgens, G.; Müller, M.; Fukuoka, S.; Koch, M.H.J. Biophysical Characterization of Lipopolysaccharide and Lipid A Inactivation by Lactoferrin. Biol. Chem. 2001, 382, 1215-1225. [CrossRef]

28. Rossi, P.; Giansanti, F.; Boffi, A.; Ajello, M.; Valenti, P.; Chiancone, E.; Antonini, G. Ca ${ }^{2+}$ Binding to Bovine Lactoferrin Enhances Protein Stability and Influences the Release of Bacterial Lipopolysaccharide. Biochem. Cell Biol. 2002, 80, 41-48. [CrossRef]

29. Aguilera, O.; Quiros, L.M.; Fierro, J.F. Transferrins Selectively Cause Ion Efflux through Bacterial and Artificial Membranes. FEBS Lett. 2003, 548, 5-10. [CrossRef]

30. Ochoa, T.J.; Noguera-Obenza, M.; Ebel, F.; Guzman, C.A.; Gomez, H.F.; Cleary, T.G. Lactoferrin Impairs Type III Secretory System Function in Enteropathogenic Escherichia Coli. Infect. Immun. 2003, 71, 5149-5155. [CrossRef] [PubMed]

31. Atef Yekta, M.; Verdonck, F.; Van Den Broeck, W.; Goddeeris, B.M.; Cox, E.; Vanrompay, D. Lactoferrin Inhibits E. coli O157:H7 Growth and Attachment to Intestinal Epithelial Cells. Vet. Med. 2010, 55, 359-368. [CrossRef]

32. Kieckens, E.; Rybarczyk, J.; Barth, S.A.; Menge, C.; Cox, E.; Vanrompay, D. Effect of Lactoferrin on Release and Bioactivity of Shiga Toxins from Different Escherichia coli O157:H7 Strains. Vet. Microbiol. 2017, 202, 29-37. [CrossRef]

33. Dierick, M.; Van der Weken, H.; Rybarczyk, J.; Vanrompay, D.; Devriendt, B.; Cox, E. Porcine and Bovine Forms of Lactoferrin Inhibit Growth of Porcine Enterotoxigenic Escherichia coli and Degrade Its Virulence Factors. Appl. Environ. Microbiol. 2020, 86, e00524-e20. [CrossRef]

34. Giansanti, F.; Leboffe, L.; Pitari, G.; Ippoliti, R.; Antonini, G. Physiological Roles of Ovotransferrin. Biochim. Biophys. Acta 2012, 1820, 218-225. [CrossRef] [PubMed]

35. Legros, J.; Jan, S.; Bonnassie, S.; Gautier, M.; Croguennec, T.; Pezennec, S.; Cochet, M.F.; Nau, F.; Andrews, S.C.; Baron, F. The Role of Ovotransferrin in Egg-White Antimicrobial Activity: A Review. Foods 2021, 10, 823. [CrossRef] [PubMed]

36. Ibrahim, H.R.; Iwamori, E.; Sugimoto, Y.; Aoki, T. Identification of a Distinct Antibacterial Domain within the N-Lobe of Ovotransferrin. Biochim. Biophys. Acta 1998, 1401, 289-303. [CrossRef]

37. Ibrahim, H.R.; Sugimoto, Y.; Aoki, T. Ovotransferrin Antimicrobial Peptide (OTAP-92) Kills Bacteria through a Membrane Damage Mechanism. Biochim. Biophys. Acta Gen. Subj. 2000, 1523, 196-205. [CrossRef]

38. Beeckman, D.S.A.; Van Droogenbroeck, C.M.A.D.; De Cock, B.J.A.; Van Oostveldt, P.; Vanrompay, D. Effect of Ovotransferrin and Lactoferrins on Chlamydophila Psittaci Adhesion and Invasion in HD11 Chicken Macrophages. Vet. Res. 2007, 38, 729-739. [CrossRef]

39. Van Droogenbroeck, C.M.A.D.; Beeckman, D.S.A.; Harkinezhad, T.; Cox, E.; Vanrompay, D. Evaluation of the Prophylactic Use of Ovotransferrin against Chlamydiosis in SPF Turkeys. Vet. Microbiol. 2008, 132, 372-378. [CrossRef]

40. Van Droogenbroeck, C.M.A.D.; Dossche, L.; Wauman, T.; Van Lent, S.; Phan, T.T.T.; Beeckman, D.S.A.; Vanrompay, D. Use of Ovotransferrin as an Antimicrobial in Turkeys Naturally Infected with Chlamydia Psittaci, Avian Metapneumovirus and Ornithobacterium Rhinotracheale. Vet. Microbiol. 2011, 153, 257-263. [CrossRef]

41. Van Droogenbroeck, C.M.A.D.; Vanrompay, D. Use of Ovotransferrin on a Turkey Farm to Reduce Respiratory Disease. Vet. Rec. 2013, 172, 71. [CrossRef]

42. González-Chávez, S.A.; Arévalo-Gallegos, S.; Rascón-Cruz, Q. Lactoferrin: Structure, Function and Applications. Int. J. Antimicrob. Agents 2009, 33, 301.e1-301.e8. [CrossRef]

43. Sessa, R.; Di Pietro, M.; Filardo, S.; Bressan, A.; Rosa, L.; Cutone, A.; Frioni, A.; Berlutti, F.; Paesano, R.; Valenti, P. Effect of Bovine Lactoferrin on Chlamydia Trachomatis Infection and Inflammation. Biochem. Cell Biol. 2017, 95, 34-40. [CrossRef]

44. Johnson, R.K.; Nielsen, M.K.; Casey, D.S. Responses in Ovulation Rate, Embryonal Survival, and Litter Traits in Swine to 14 Generations of Selection to Increase Litter Size. Anim. Sci. J. 1999, 77, 541-557. [CrossRef]

45. Rooke, J.A.; Bland, I.M. The Acquisition of Passive Immunity in the New-Born Piglet. Livest. Prod. Sci. 2002, 78, 13-23. [CrossRef]

46. Rybarczyk, J.; Khalenkow, D.; Kieckens, E.; Skirtach, A.G.; Cox, E.; Vanrompay, D. Lactoferrin Translocates to the Nucleus of Bovine Rectal Epithelial Cells in the Presence of Escherichia coli O157:H7. Vet. Res. 2019, 50, 75. [CrossRef] [PubMed]

47. de Brito, C.R.C.; Varela Junior, A.S.; Gheller, S.M.M.; Acosta, I.B.; Anciuti, A.N.; Gatti, N.L.S.; Silva, E.A.; Knabah, N.W.; Corcini, C.D. High-Speed Centrifugation of Extender of Freeze-Thaw Boar Semen. Reprod. Domest. Anim. 2021, 56, 821-825. [CrossRef] [PubMed]

48. Ko, K.Y.; Mendoncam, A.F.; Ismail, H.; Ahn, D.U. Ethylenediaminetetraacetate and Lysozyme Improves Antimicrobial Activities of Ovotransferrin against Escherichia Coli O157:H7. Poult. Sci. 2009, 88, 406-414. [CrossRef]

49. Valenti, P.; de Stasio, A.; Mastromerino, P.; Seganti, L.; Sinibaldi, L.; Orsi, N. Influence of Bicarbonate and Citrate on the Bacteriostatic Action of Ovotransferrin towards Staphylococci. FEMS Microbiol. Lett. 1981, 10, 77-79. [CrossRef]

50. Superti, F.; Ammendolia, M.G.; Berlutti, F.; Valenti, P. Ovotransferrin. In Bioactive Egg Compounds; Huopalahti, R., López-Fandiño, R., Anton, M., Schade, R., Eds.; Springer: Berlin/Heidelberg, Germany, 2007; pp. 43-50. [CrossRef]

51. Kolbl, O. Untersuchungen Uber Das Vorkommen von Miyagawanellen Beim Schwein. Wien. Tierarztl. Monatsschrift 1969, 56, 355-361.

52. Vanrompay, D.; Ducatelle, R.; Haesebrouck, F. Diagnosis of Avian Chlamydiosis: Specificity of the Modified Giménez Staining on Smears and Comparison of the Sensitivity of Isolation in Eggs and Three Different Cell Cultures. J. Vet. Med. Ser. B 1992, 39, 105-112. [CrossRef]

53. De Puysseleyr, L.; De Puysseleyr, K.; Vanrompay, D.; De Vos, W.H. Quantifying the Growth of Chlamydia Suis in Cell Culture Using High-Content Microscopy. Microsc. Res. Tech. 2017, 80, 350-356. [CrossRef] [PubMed] 
54. Mayr, A.; Bachmann, P.A.; Bibrack, B.; Wittman, G. Quantitative Bestimmung Der Virusinfektiosität (Virustitration). In Virologische Arbeitsmethoden; Mayr, A., Bachmann, P.A., Bibrack, B., Wittmann, G., Eds.; VEB Gustav Fisher Verlag: Jena, Germany, 1974; pp. 35-39.

55. De Puysseleyr, K.; De Puysseleyr, L.; Geldhof, J.; Cox, E.; Vanrompay, D. Development and Validation of a Real-Time PCR for Chlamydia Suis Diagnosis in Swine and Humans. PLoS ONE 2014, 9, e96704. [CrossRef]

56. Verminnen, K.; Van Loock, M.; Hafez, H.M.; Ducatelle, R.; Haesebrouck, F.; Vanrompay, D. Evaluation of a Recombinant Enzyme-Linked Immunosorbent Assay for Detecting Chlamydophila Psittaci Antibodies in Turkey Sera. Vet. Res. 2006, 37, 623-632. [CrossRef] [PubMed]

57. Schindelin, J.; Arganda-Carreras, I.; Frise, E.; Kaynig, V.; Longair, M.; Pietzsch, T.; Preibisch, S.; Rueden, C.; Saalfeld, S.; Schmid, B.; et al. Fiji: An Open-Source Platform for Biological-Image Analysis. Nat. Methods 2012, 9, 676-682. [CrossRef] [PubMed]

58. De Vos, W.H.; Van Neste, L.; Dieriks, B.; Joss, G.H.; Van Oostveldt, P. High Content Image Cytometry in the Context of Subnuclear Organization. Cytom. Part A 2010, 77A, 64-75. [CrossRef] [PubMed] 